\title{
The origin and development of Sufism in the regions of Bengal and Assam in India
}

\author{
Nasir Raza Khan', Madhubanti Talukdar², \\ ${ }^{1}$ An Associate Professor at the India Arab Cultural Centre, Jamia Millia Islamia New \\ Delhi, and the Director of a research project on "Sufism and Multiculturalism in India: \\ Its Impact on Contemporary Society" funded by the Indian Council of Social Science \\ Research (ICSSR). \\ ${ }^{2}$ A Research Assistant working on the ICSSR-funded research project "Sufism and \\ Multiculturalism in India: Its Impact on Contemporary Society".
}

\begin{abstract}
Sufism refers to the mystical dimension of Islam, which, moving away from its rigid doctrinal form, speaks of self-realization, love, submission, and intense personal devotion as being the path to reach God. This paper attempts to understand Sufism and its essential principles, proceeding to trace its establishment and evolution in the Indian subcontinent, with a special focus on Bengal and Assam. The paper discusses the development of Sufism in the regions of Bengal and Assam by situating it in its precise historical and cultural context, exploring at length its interactions with the Bhakti movement and Buddhist Sahajiya tantrism, its impact on the folk art, culture and literature of the regions, and its role in shaping the socio-political climate of the regions over the ages. Lastly, the paper attempts to comment upon how Sufism, with its inherent variations and contradictions, survives in these regions today, and the significance that it holds for the people in contemporary times. In doing so, the paper attempts to understand whether Sufism and its ideals can become useful in promulgating a culture of peace and tolerance in an increasingly polarized and divided society
\end{abstract}

Keywords: Origin, Development, and Region

\section{INTRODUCTION}

Sufism - the mystical dimension of Islam, moves away from its rigid doctrinal form and speaks of an intuitive or spiritual awareness of God that transcends empirical experience. The Sufis believe that realization of one's own self, along with intense personal devotion and complete surrender, allows people to experience, understand, or to be united with the Divine. For the Sufis, it is important not to merely believe in God but to experience his existence with all of one's senses as "Rahman" ('The Merciful') and "Rahim" (The Compassionate) (Aquil, 2020). In the Indian subcontinent, Sufism arrived in the mid-11th century, when Shaikh Safiuddin Kaziruni became the first Sufi shaikh to settle in Multan. It gradually spread to all parts of the country, travelling with the Sufi saints as they disseminated the message of equality, love, tolerance and mutual respect. The regions of Bengal and Assam too, welcomed the Sufis with open arms, which resulted in them managing to amass a large number of followers as well as their teachings being incorporated into the local folk cultures of these regions. This paper explores how Sufism was 
introduced in the regions of Bengal and Assam, tracing its evolution through the ages to comment upon its present form. It attempts to understand how Sufism, with its inherent variations and contradictions, survives in these regions today, and the significance that it holds for the people. In doing so, the paper tries to understand whether Sufism and its ideals can become useful in promulgating a culture of peace and tolerance in an increasingly polarized and divided society.

\section{METHOD}

In order to chart a brief history of Sufism in eastern India, with a focus on Bengal and Assam, this paper attempted to collate available information on the subject, relying mainly on secondary sources like books, journal and newspaper articles, and newsletters. Data collected was critically analyzed to understand the role that Sufism plays in these regions today.

\section{RESULT AND DISCUSSION}

\section{A. Understanding Sufism}

According to A'ishah Al-Ba'Uniyyah, a leading scholar of Islamic history, Sufism involves an inward turn towards one's own self, which is the first step for taking the journey of opening up oneself to an authority who is more powerful and demanding than any other, that is, God. In this process of opening one's inner self there takes place an eradication first of selfishness and then of the sense of self itself, thus leading the spiritual seeker to be overwhelmed in their union with God (Al-Bā'ūnīyah and Homerin, 2018). There are four essential roots of Sufism. These are Repentance (tawbah), Sincerity (ikhlas), Recollection (dhikr) and Love (mahabbah). A person wishing to experience the Divine must first repent and discipline human nature, which is inherently selfish, so that they might open up their heart to be able to see God's grace within it. Only then can the believer cultivate a sincere devotional life to God and serve humanity based on love. Remembrance of God becomes an essential means to attain and maintain a religious life of love in Sufism. Remembrance here refers both to a process of purifying oneself of selfishness and hypocrisy, and a mystical state. The principle of Repetance, or tawbah essentially means 'to return'. It includes feeling remorse for sin, abstention from it, and the resolution not to return to it. The principle of Sincerity involves worshipping God sincerely, dedicating faith to Him alone. Lastly, the principle of Love involves the total effacement of one's own self such that one is consumed in one's beloved. Humility is a quality of love that is born of knowledge. Arrogance is its opposite, born of ignorance, and it leads to pain and woe. (Al-Bā'ūnīyah and Homerin, 2018).

The Sufis are known as 'Auliya Allah', meaning Allah's friends. They aim to arrive at Haqeeqa, the Truth, not through prayer, fasting or other earthly rituals, but through the security of the heart and generosity of the soul. The Sufis believe that through a rigorous discipline of selfmortification (mujahida) and purification of one's soul, one manages to reach fana, which is the highest maqam, where the self-ceases to exist (Dehlvi, 2009).

Sufis trace their spiritual enlightenment through a chain of transmissions that go back to Prophet Muhammad. They are grouped into different silsilas or orders; these are chains of lineages 
through which their history can be traced. A silsila is akin to a "spiritual genealogy", where subsequent Sufi shaikhs would pass on their teachings to their khalifas (disciples/ spiritual descendants). The first major Sufi order was the Qadiri Order established by Shaikh Abdul Qadir Jilani who was famous for his many miracles, and his idea of jihad of the self. Shaikh Abu Ishaq Shami of Chisht-e-Sharif in Afghanistan was the founder of the Chishtiya order. The Nizami and Sabri orders are two of the many branches of the Chishtiya silsila. The Suhrawardi Order was founded by Shaikh Shihabuddin Suhrawardi and the Shattari Order is a branch of this order. Khwaja Ahmad Yasavi founded the Yasavi Order, under whom many Turkish nomadic tribes were converted to Islam.

The Kubrawiya Order developed by Shaikh Najmuddin Kubra came up with an elaborate symbolism of colours to interpret the revelation of lights seen during meditation. Offshoots of this order include the Firdawsiya and Hamdaniya Orders. The Rifai Order, founded by Shaikh Ahmad Rifai, is known for its extravagant practices and strange miracles. The followers of the Mevlavi Order are known as the "whirling dervishes," and hope to establish communion with the Divine through love, poetry, music and meditation. The Naqshbandi Order, established by Khwaja Bahauddin Naqshband of Bukhara, is a sober order that does not believe in dance or musical assemblies as a means of attaining superior spiritual states (Dehlvi, 2009). There are subtle differences in the beliefs, teachings and practices of various silsilas. The development of such silsilas placed Sufism on a firm and organized basis, with the spiritual hierarchy giving Sufis greater respectability and a stronger base of defense against the onslaught of the orthodox ulema (Rizvi, 1978).

Because of the open-endedness and fluidity of their beliefs and practices, and their tendency to incorporate and accommodate a wide range of belief systems within their own, Sufis have often had to bear the wrath of the orthodox and the reformists. From time immemorial, they have been accused of perpetuating superstition, "Shirk" or idolatry, labelled as heretics, tortured and even killed, with the tombs of venerated saints and masters destroyed. However, notwithstanding numerous efforts to the contrary, Sufism has managed to brave all odds, and survive, and continues to attract followers throughout the world today.

\section{B. The origin and development of Sufism in India}

The origins of Sufism can be traced back to ninth-century Baghdad, which espoused and spread the message of finding one's own personal connection with God through mystical verses, poetry and music (Aquil, 2020). In the Indian subcontinent, Sufism arrived in the mid-11th century, when Shaikh Safiud-Din Kaziruni became the first Sufi shaikh to settle in Multan. He was known as the protector of travellers (Dehlvi, 2009). After the annexation of Punjab by Mahmud of Ghazni, many Sufis settled in the area. Finally, following a spate of Mongol invasions in Iran and Central Asia in the 13th century, India saw a great exodus of scholars and holy men from these regions who came and settled here. It was not too long before Delhi became the heart of the Sufi movement, and came to be known as Qubbatu'i Islam (Cupola of Islam). (Rizvi, 1978). 
On arriving in India, the Sufi shaikhs proceeded to immerse themselves in Indian society, learning about its culture and traditions, and trying to understand the minds and hearts of the common people. They preached - al khalq-o-ayalullah, meaning, all of humanity belongs to the family of God (Dehlvi, 2009). They spread the message of love, devotion and cosmic harmony, and in doing so always remained open to the truths of other faiths, instead of rejecting them. They read Sanskrit texts and other canonical texts of Hindu philosophy and mythology, and also developed connections with Hindu sages, yogis, saints and wise learned men, for a better and fuller understanding of the existing culture in India.

Gradually, the Sufis began to travel to various corners of the subcontinent. They quickly became accepted wherever they went because they disseminated ideas that resonated with everyone. Moving away from strict and rigid ideologies that people found difficult to connect to, they spoke of everyday things and everyday conduct. This made their teachings understandable, palatable and acceptable to the common masses. They preached and wrote in local languages and dialects, and often used poetry and music to communicate their ideas. The Sufis worked hard to remove mistrust between communities. They talked about mutual respect and peaceful coexistence. Not only this, their non-discriminatory attitude appealed to the masses, especially to the lower castes, who were brought into the folds of religion and treated with a form of dignity and kindness that they had not experienced before. In a society characterized by strife and division, frequent regime changes and intense political turbulence, the Sufis provided solace and refuge to the people, listening to their problems, providing simple solutions, advice, comfort and protection to them. Soon, Sufi khanqahs became centres of cultural synthesis and communal harmony.

\section{Sufism in Bengal}

Although Muslim rule in Bengal was established formally in 1204 with the arrival of Bakhtiyar Khalji, it is commonly believed that Sufis from Arabia and Persia had begun to arrive in the region even before that. Post 1204, Muslim immigrants began to arrive in Bengal from Turkey, Central Asia, Persia, Arabia, Iraq, Iran, Yemen and North India as administrators, traders, soldiers in the army, preachers, teachers, physicians, artisans and fortune seekers (Ellus, et al., 2020). This included a large number of Sufi saints and Islamic scholars, who settled in various parts of Bengal. They established khanqahs throughout the region in order to impart knowledge, or talim, to their disciples, train them in tajkia-e-nafs, i.e. Reformation of the Self, and to serve people (khidmat-e-khalq) irrespective of their caste, creed, and religious differences (Matin, 2018).

Jalaluddin Tabrizi, one of the earliest Sufi saints to arrive in Bengal, was responsible for introducing the Suhrawardi Order in this region. He settled in the area around Devatalla near Pandua, in Malda, presently in West Bengal. Upon his arrival he demolished a temple, constructed a khanqah in its place, and gradually managed to convert a large number of 'kafirs' to Islam. Eventually he became so famous in Bengal that Devatalla was renamed as Tabrizabad, and his aastaana (dwelling place) continues to attract hundreds of followers to this day (Rizvi, 1978). Sayyid Jalal bin Ahmed Kabir, who was known as Makdum Jahaniya, was the second Sufi shaikh 
of this order to visit Bengal. Shah Jalal Mujarrad Kunyayi, who also belonged to this order, settle in Sylhet (Ismail, 1989).

Sayyid Shah Abdullah Kirmani, a disciple and khalifah of Khwaja Moinuddin Chishti, was the founder of the Chishti order in Bengal. His khanqah, the Khustigiri Dargah Sharif in Birbhum, remains a popular pilgrimage spot for Hindus as well as Muslims to this day. Shaikh Akhi Sirajuddin Uthman, a khalifah of Shaikh Nizamuddin Auliya, was another prominent Chishti saint in Bengal. He was succeeded by his khalifah Shaikh Ala-ul Haq bin Asad Lahori Bengali, who was in turn succeeded by his son and khalifah Shaikh Nuru'l-Haqq, also known as Shaikh Nur Qutub-i-Alam. Shaikh Anwar, his son, was also a Chishti saint. Shaikh Husain Dhukarposh (Dustridden) was the most prominent disciple of Nur Qutub-i-Alam and managed to amass a large number of followers in Bengal (Ismail, 1989).

Several other Sufi silsilas were established in Bengal. These were the Qalandari, introduced by Shah Safiuddin Shahid, who was a disciple of Bu Ali Shah Qalandar of Panipat; the Madari, introduced and made popular in Bengal by Shah Ala and Shah Sultan Husayn Muriyah Barhina, who were disciples of Shah-i-Madar; the Shattariyya, whose founder was Shah Abdullah of Bukhara and whose leading saints included Shaikh Muhammad 'Ala' and Shaikh Ruknuddin; the Naqshbandi, introduced in Bengal by Shaikh Hamid Danishmand Bengali, a disciple and khalifah of Shaikh Ahmad Sirhindi; the Adhami, believers in the legendary saint Khidr, whose followers were known as 'Khidriyah'; and the Qadiri, which was brought to Bengal by Hadrat Shah Qamis, one of the descendants of Abdul Qadir Jilani. The disciples of Diwan Abdur Rashid of Jaunpur also established Qadiriyya centres in Bengal (Ismail, 1989). Other smaller orders included the Furfura, the Sureshsari, the Maizbhandari, the Gazipuri, the Azangachi, the Atrashi, the Fultoli, and many others (Matin, 2018).

The Sufis, upon their arrival, were quick to immerse themselves in Indian society. They invested themselves in learning about their host societies and their people by proceeding to learn their languages, and to understand their philosophy and bent of mind by interacting with Hindu yogis, saints, and philosophers. In Bengal, the ideas of the Sufi saints were echoed in the kirtans and samkirtans of the Bhakti movement which too talked about love, devotion and surrendering one's own self in pursuit of inner light. Like the Sufi shaikhs, the Bhakti saints advocated reaching a state of ecstasy where one could have a transformative spiritual experience, through devotional poetry, songs and rapturous dancing (Rizvi, 1978).

The spread of Islam in Bengal was a predominantly rural phenomenon, based mainly in the villages. A merging of Sufism with vernacular strands of Vaishnavism, tantrism and other local folk cults resulted in the formation of a rich repertoire of religious beliefs and practices, especially in the lower echelons of the society - a distinctive Bengali folk culture which was neither Hindu, nor Muslim, but at the same time, both (Trottier, 2000). The conversation between Sufism and the Bhakti movement is a much-studied phenomenon today. A number of parallels can be drawn between the two, for instance, the ideas of 'dasha' and 'hal' (ecstacy), Krishnanama and Zikr (Remembrance of God/ Recital of God's name), kirtana and sama (the medium of ecstatic 
communion with God through musical gatherings) and a deep pantheistic monotheism (Rahman, 2018). In Bengal, the intermingling of Sufism and the Bhakti movement resulted in many Muslim poets developing a Vaishnava inclination who talked about religious syncretism, tolerance and synthesis in their poetry. Some of them were Syed Mortaza, who was a Sufi pir and at the same time a Vaishnava poet, Lal Mahmud and Chand Qazi, who were devotees of Krishna, and the famous and greatly revered Hasan Raja, who talked about 'Radha' and 'Khoda' as the same being (Rahman, 2018).

The three-fold interaction between Sufism, the Bhakti movement pioneered by Chaitanya Mahaprabhu, and Buddhist Sahajiya tantrism (Sahajiya means a return to one's own self, to what is 'sahaja' - inborn, natural, effortless), which was premised upon an anti-caste rhetoric, religious tolerance, and the power of love, gave birth to the baul-fakir tradition of Bengal in the late 15th century who divinized human love, sang of God's love manifested in Nature, and of love as being the path to understand or reach God. The bauls and fakirs believe in Dehatattwa - that is, the human body is the locus and means of realizing the essence of God. It is believed that the gurudisciple relationship in this tradition has been borrowed from the Sufi system, where one's 'guru' is an entity in whom the essence of the divine is merged with the human (Trottier, 2000).

Another such development was the birth of the Kartabhaja sect, who talked about One God incarnate in 'Karta'. Here too, one saw a guru-disciple relationship where the Mahasaya was the spiritual guide who taught the 'correct path' to his 'baratti' or disciples. The mantra of this sect was to be repeated five times a day as a means of purifying oneself, obtaining prosperity, and achieving salvation. Fridays were sacred for the Kartabhajas, which were to be spent in meditation and religious discussion. They also believed in abstaining from meat and wine. The Kartabhaja sect did not recognize differences between Hindus or Muslims, or people of various castes. They encouraged everyone to live and eat together. For the Kartabhajas, no outward sign of adherence to the sect was important or required; the only thing necessary was bhakti, i.e. devotion (Rahman, 2018).

The resonances of the fusion of Hindu and Islamic traditions were felt in Bengal's folk music, especially in its Marefati and Murshidi songs (Sinha, 2014), its folk literature - the Mangal Kavyas, Pir and Sufi literature, Punthi literature, Panchalis and Geetikas, notable among which were the Purba Banga Geetika and the Mymensingh Geetika (Rahman, 2018) as well as its folk art - Patachitra, and the practices of the artists. From the 16th to the 18th centuries, numerous local "Pir cults" developed in Bengal centred around some Muslim saints (pirs) and mythical heroes whose identities were uncertain. These cults included members of both communities, the Hindus and the Muslims. Some important and popular pirs include Khawajah Khizir, Pir Badr, Zindah Ghazi, Madar Pir, and Panch Pir. Adoration and reverence of the 'pir' became a popular motif in Hindu poetry. In the 17th century, the Pir Panchalis saw an intermingling of the 'Sharma thakur' of the Buddhists, the pir of the Muslims and the Narayan of the Hindus. The scribes of these ballads were Hindus, the singers were Muslims, and the music to which they were tuned were composed by people of both communities. In these ballads, Rama and Rahim were often spoken of in the same breath and talked about as the same entity. In the 19th century, Faizullah, the author of the 
Satya Pir Panchali, began his work with a 'vandana', paying respect to all great personalities, both Hindu and Muslim. In the panchali he talked about 'Bismillah' as being merely another name for the one who is known as Niranjan. In his opinion, Vishnu and Bismillah were not at all distinct, but one and the same (Rahman, 2018).

Throughout the 15th, 16th, 17th and 18th centuries the Sufi saints remained in conversation with yogis. Being enamoured with the philosophy of yoga as a form of devotion and communion with the Divine, the Sufis proceeded to translate the Amritakund (The reservoir of Nectar), a religious book of the Natha Yogis, from Sanskrit to Bengali. Sayyid Sultan of Sylhet fused the philosophies of Yoga and Sufism and composed the Jnana-Pradip and the Jnana-Chautisa. The Gangastak (hymn to the Ganga), was composed by Daraf Khan, a well-known Muslim poet from Tribeni, Hooghly in Sanskrit, which is recited even today, by pious Hindus after taking a bath in the holy Ganges. According to Jagadish Narayan Sarkar, during the period of Muslim rule in Bengal, the Hindus and the Muslims came in such close and prolonged contact with each other that they eventually came to have common objects of worship. During illness, famine or personal troubles, the members of one community would often appear to the Gods and saints of the other, failing their own (Rahman, 2018).

When the Sufis arrived in Bengal, they found Bengali society to be deeply divided and casteridden, with people belonging to the lower castes excluded from the folds of religion, and deprived of a life of respect and dignity. Their message of love, respect and equality drew thousands of people to their khanqahs, many of who converted to Islam. The Turk-Afghan rulers of Bengal, comprising the elite ashrafs, were merely interested in consolidating their power and remained distanced and divorced from the local rural populations who they looked down upon. Harbouring a negative attitude towards Bengali cultural symbols, and especially the language, they were disinterested in converting the people to their faith. Islam was thus not an alien system imposed upon the people of Bengal by their rulers. The people embraced Islam of their own volition under the influence and inspiration of the Sufis, whose teachings they incorporated and gradually assimilated into their agrarian worldview. Many of the people who accepted Islam continued to maintain their pre-Islamic Sahajiya roots (Dasgupta, 2004).

The Sufi saints did not restrict themselves to the fold of spirituality and mysticism alone, and often played an active role in social, religious and cultural reform in Bengal, by setting up mosques, makhtabs and madrasas, educating the masses and spreading awareness among them regarding their rights and duties. They also supplied food to the hungry, medical support to the ailing and diseased, and shelter to the victims of floods, famine and other natural disasters. Pir Abu Bakr Siddique of Furfura Sharif in Hooghly is one such celebrated Sufi saint known for his immense contribution in the field of education, social work and religious reform. He worked hard to eradicate superstition from the minds of people and to develop a scientific temper among them. He patronized several Bengali weeklies and socio-religious journals such as Shariat-e-Islam Darpan, Mihir-o-Sudhakar, The Mussalmaan, Islam Hitoishi, Banganoor, etc, which included debates and discussions on various issues like dowry, the importance of women's education, the oppression of the people by zamindars and moneylenders, and the importance of scientific and 
technical education. He also built charitable centres, hospitals, and community centres for the welfare of the common people. During the non-cooperation movement and the Khilafat agitation, he organized hundreds of public meetings and rallies throughout Bengal, recruiting followers and garnering support for the cause. He envisioned a world where people from all religions, communities, castes and creeds would coexist peacefully and with mutual respect, without impinging on each other's beliefs and rights. He referred to this utopic society as the 'Dar-ulAman' - the land of peace. His activities earned him the title of 'Mujaddid-e-Zaman' (Reformer of the Age). Pir Abu Bakr Siddique believed the role of Sufism to be "Khidmat-e-Khalq" i.e. serving the people and Tahfooz-e-Deen, i.e. preservation of religion (Matin, 2018).

The relationship of the Sufi saints with the State was ambivalent. While certain saints, especially those of the Chishtiya Order, believed in maintaining a distance from the political elite, several others involved themselves in the internal politics of the State, and sometimes tried to influence the Sultans in moulding their politics according to their desires. Most of the rulers were devoted to one or the other Sufi saint, and approached them for advice, especially during times of crises.

\section{Sufism in Assam}

In Medieval times, Assam was a part of Bengal, along with certain sections of Bihar and Orissa. It is thus needless to discuss the growth and development of Sufism in Assam separately. What needs to be explored is how the Sufis of Assam contributed to the creation of a pluralistic, multi-cultural, and peaceful society.

It is commonly believed that Shah Jalal Mujarrad had arrived in the Karimganj district of Assam with three hundred and sixty khalifas to spread the message of Islam there. Hazrat Shah Badruddin, who was the first prominent Sufi of Assam, was one of his companions. He played an important role in the war that led to the Muslim conquest of Sylhet. Other companions of the Shaikh included Sheikh Sikandar, Shah Ziauddin of Yemen, Shah Abdul Malik, Hazrat Khaja Hassan, Shah Monaf Monaishah, Sayeed Khaza Ambar Shah Yemoni, Shah Abdul Karim, Shah Abdullah, Mawlana Mozaid Uddin Chowdhury, Mawlana Najib Ali Chowdhury, Hazrat Kanu Shah, who was known for his many miracles, and Kari Nazib Ali (Talukdar, 2015). Hazrat Shah Adam Khaki, Mirul Arefin, and Shah Natawan were the most renowned and revered Sufi saints of the Barak valley (Hoque \& Talukdar, 2018).

The Sufis in Assam advocated the renunciation of materialism and leading simple, austere lives, one that was resigned to Allah. They were deeply invested in promoting humanism with its ideals of peace, mutual trust, respect, love, tolerance and harmony and ensuring that the social equilibrium remained undisturbed. They also became apostles of righteousness and knowledge who came forward to protect the weak whenever the need arose. They proclaimed - "Hindu ki Mussalmaan, ek'i Allah'r farman. Amrar monot bhed bhan naai" meaning both Hindus and Muslims are children of the same God. Such divisions have no place in our hearts (Hoque \& Talukdar, 2018). 
The Sufis played a major role in creating a pluralistic and syncretic society in Assam. The foremost apostle of this syncretic culture was the Sufi shaikh Chand Khan, popularly known as Chandasi. Although a Muslim by birth, Chand Khan was deeply interested in Vaishnava philosophy, and authored the biography of Gopaldeva, a Vaishnava preacher who was known for many miracles. He also composed several kirtans as well as jikirs (songs written in praise or remembrance of God) (Mumtaz, 2010). The jikirs included Islamic religious teachings written in the pattern of Assamese Vaishnava poetry (Begum, 2020) and were first introduced in Assamese society by a Sufi saint named Hazrat Miran Shah from Baghdad, who came to be known as Azan Faqir. Azan Faqir was also known for his Jarigan and Marshiya, songs which spoke of stories and legends from Islamic history, in a form that was adapted to Assamese society and rituals. He was greatly inspired by the naam gaan composed by the Vaishnava saint Mahapurush Shrimanta Shankardeva (Begum, 2020). Azan Faqir wrote - "There is no feeling of difference in my mind, Oh God/ Indeed there is no difference/ Hindu and Mussalmaan are the creation of the same God/ Takes the name of the same God/ At the end of life Hindus would be cremated Muslims buried/ and Dust would merge with Dust" (Mumtaz, 2010). Because of the influence of these songs, many Persian and Arabic words came to be included in the Assamese language (Begum, 2020).

The tombs of several prominent Sufi saints, including those of Peer Shah Madhar, Syed Raushan Ali Chishti (known as 'Boga Baba') of Dibrugarh, Shah Gazi Aksar, Laskar Shah, Lai Fakir and Kala Fakir of Golaghat, Shah Makdum Shah of Sijubari, Shaikh Nasiruddin Baghdadi of Jaleshwar, Zahir Auliya of Ulubari, and Shaikh Moiunuddin Shah of Ponchalori were venerated by the Assamese irrespective of their religious and caste identities. Several legends and miracles were attributed to some of these Sufis, stories which have today become a part of the popular culture of Assam (Mumtaz, 2010). At these Dargahs, Hindus used to pray to the saints in a way that resembled the Muslim way of offering namaz - kneeling down, their head touching the ground. The Muslims, in turn, prayed to the Mother Goddess in case of the outbreak of smallpox epidemics. Many Muslim families in Kamrup, Mongoldoi and Nowgong districts participated in Manasa Puja, i.e. veneration of the Goddess of Snakes (Mumtaz, 2010).

\section{E. The debates over "true" Islam}

Dargahs and healing sites have routinely been looked down upon both by the modernist discourse, which has seen the practices within them as irrational or superstitious, and by Reformist Islam, which views the practices as amounting to idolatry, or 'Shirk', and hence, a violation of "true Islam". In the later part of the 16th century the first signs of Reformation could be seen among the Indian Muslims. There was a sustained attempt at "purifying" Islam, ridding it of its Hindu influences, especially in the east. The Naqshbandi Order, closer to orthodoxy than any other Sufi silsila, was the first to emphasize on the need for reformation and revivalism in India (Ismail, 1989).

Vigorous efforts were launched by the orthodox ulemas and traditionalists to formalize Bengali Islam, ridding it of its vernacular character. In some places, this was accompanied by open hostility against and persecution of the heterodox groups such as the bauls and the fakirs. The 
practice of sajdah of the disciple (murid) before the pir was considered to be sacrilegious by orthodox Muslims (Rahman, 2018). Such reformist movements, driven largely by an anxiety on the part of Bengali Muslims regarding their religious and cultural identity which was perceived in the Muslim world to be too "Hinduized" and therefore corrupt and impure, continued well into the 20th century, and are still at work today (Trottier, 2000).

Sociologist Imtiaz Ahmad feels that these debates over what is "true" Islam and what is not arise from the tendency to understand Islam through the written text alone, or to regard it as a unified system when it is actually not. There is no fixed or immutable idea of Islam anywhere in the world. Instead, like all other religious traditions, it has the inherent potential to be shaped and ordered into distinctive patterns of belief through its interactions with the temporal, societal, and environmental conditions of the countries and regions where it has travelled to. What is held to be the "true" form of Islam is actually one practiced by the intellectual and religious elite, which is abstract, formal and legalistic, which regards local and popular interpretations and folk expressions of the tradition as less ordered and less complete versions of religious experience (Ahmad \& Reifeld, 2004).

Anthropologist Talal Asad too, has argued that neither "Great" nor "Little" tradition(s) within Islam is "more real" than the other. This divide itself is Orientalist, assuming the existence of an analytical category called "Islam" which does not exist. Islam and Islamic are not temporal, autonomous and unchanging forces or fixed categories of analysis; instead, Islam is best understood as a discursive field (Asad, 2009).

\section{F. Sufism in Bengal and Assam today: realities and possibilities}

Sufism is not a monolith. In the regions of Assam and Bengal, Sufism assumed a diverse and heterogeneous character, with subtle as well as significant differences between the various orders, their beliefs and practices (Matin, 2018). Certain orders like the Naqshbandi and at times even the Suhrawardi were known to be antagonistic and even openly hostile towards non-Muslims (Rizvi, 1978). In spite of this, it is interesting to note how Sufism is perceived by common people today. In popular memory, Sufism is a protective umbrella far away from the rigidity of textual religion, a source of refuge, comfort and support for everyone, especially the downtrodden. The Sufi Dargahs function as shared spaces which are open to all, where laws and dictates of religion are somewhat relaxed and fluid, where ambiguities and paradoxes are tolerated, and a sense of togetherness manages to develop in spite of the existence of boundaries of religion, caste, class and gender among people.

Today, a vast majority of the people who visit Sufi Dargahs in India are ones belonging to the lower socio-economic strata of society in general, and women in particular. It is common knowledge that Dargahs provide shelter, free food and medicines to the disadvantaged, and often also avenues to find work. Additionally, since Dargahs have traditionally been spaces of acceptance where everyone is welcome, they often serve as accessible public spaces for the marginalized, cutting across lines of religion and gender, to whom other places of worship are not always open. Healing remains central to all Dargahs in the Indian subcontinent, where people, 
especially those whose voices largely remain unheard, seek the blessings of the saints to help them tide over crises, to guide them in taking decisions, and to assist them in successfully dealing with their troubles and worries (Bellamy, 2011). For these people, it is easier perhaps, to rely on a wise and protective father-figure for the resolution of everyday problems, rather than to conceive the idea of troubling an all-pervading and all-powerful entity like God. Many also believe that these saints have the power to act as mediators between them and God.

The pilgrims and devotees who flock to the Dargahs manage to form communities despite keeping their individual identities intact. Through sharing and coexistence, and a shared commonality of experiences, friendships and networks of support are formed in spite of the existence of clear boundaries of caste, class and religion between people, and differences in their socio-economic and cultural locations. These boundaries, in fact, no longer remain a hindrance to people understanding each other or being there for one another, for within Dargah culture is embedded the ideal of inclusivity, tolerance, and respecting diversity. Here, their stories are received with a sympathy and understanding that is absent in the outside world, enabling them to conceive of these spaces as ones of refuge, safety and security. The roots of this inclusive Dargah culture lies in people's idea of Sufism as having an unique essence of celebrating love, peace, understanding, and coexistence.

In the regions of Bengal and Assam, Sufism remains alive in folk idioms which are the common property of all people, in popular songs, in folk art (Patachitra) and in local festivals such as 'Bera bhashan' (floating of rafts) which is a way of paying tribute to the legendary saint Khidr by all inhabitants living on the banks of major rivers in Bengal who identify as the Adhami, or the followers of the Khidiriyah Order (Ismail, 1989). In Assam, many tombs, mosques and madrasas established by venerated Sufi saints have been washed away by the Barak river, but the names of these saints are taken as a mark of respect by fishermen and boatmen whenever they cross the side of their tomb (Talukdar, 2015). Although there exists many separate Hindu and Muslim villages in Assam, the two communities continue to live together in several villages where they have separate prayer houses. The Muslims of these villages often visit the namghars of the Hindus and accept the prasad (offerings made during prayer) there, and the Hindus in turn visit the Muslim khanqahs and Dargahs to make offerings, and tie threads on trees and posts within their vicinity for the fulfillment of their wishes and desires (Mumtaz, 2010). The local customs of the land, born out of centuries of coexistence and the fusion of several different kinds of traditions remain alive among people of both communities.

\section{CONCLUSION}

In this paper, through a detailed study of the growth and development of Sufism in Assam and Bengal through the ages, an attempt has been made to establish that Sufism and its contemporary manifestations have the potential to draw people from diverse backgrounds together, and to enable them to negotiate with, understand, sympathize with, and learn from one another. Since Sufism is believed to espouse peace, tolerance, and mutual respect, the potential to embrace and celebrate diversity is inherent in it. At a time when societies all over the world are becoming increasingly intolerant and exclusionary, intent on demarcating strict boundaries of "us" and 
"them", Sufism, with its emphasis on peace and love, and its acceptance and celebration of the coexistence of various cultures, can be a potential antidote to the hatred and violence that we see around us.

A major limitation of the study is that it relies solely on secondary sources of data. The Corona Pandemic made it impossible for any fieldwork to be conducted in these regions, which leaves room for further research based on primary sources in these regions. An ethnographic study of the Dargahs of this region along with those who visit them, the musical and culinary traditions of the people, and in-depth interviews with those involved in various syncretic cults and practices would, undoubtedly, yield interesting insights on the present state of Sufism here, and the significance that it holds for the people of this region.

\section{REFERENCES}

Ahmad, I., \& Reifeld, H. (Eds.). (2004). Lived Islam in South Asia: adaptation, accommodation, and conflict. Berghahn

Books.

Al-Bā'ūnīyah, A., and Homerin, T. (2018). The principles of Sufism. Aleph Book Company. Aquil, R. (2020). Lovers of God: Sufism and the Politics of Islam in Medieval India. Routledge. Asad, T. (2009). The idea of an anthropology of Islam. Qui parle, 17(2), 1-30.

Begum, T. (2020). Vernacularization of Islam and Sufism in Medieval Assam: A Study of the Production of Sufi

Literature in Local Languages. International Journal of Research and Innovation in Social Science (IJRISS), IV(IX), 201-202.

Bellamy, C. (2011). The powerful ephemeral: Everyday healing in an ambiguously Islamic place. University of

California Press.

Dasgupta, A. (2004). Islam in Bengal: formative period. Social Scientist, 30-41.

Dehlvi, S. (2010). Sufism: the heart of Islam. HarperCollins Publications India.

Elius, M., Khan, I., Mohd Nor, M. R., Muneem, A., Mansor, F., \& Yakub Zulkifli Bin Mohd Yusoff, M. (2020). Muslim

Treatment of Other Religions in Medieval Bengal. SAGE Open, 1O(4), 2158244020970546.

Ernst, C. W. (2016). Refractions of Islam in India: Situating Sufism and Yoga. Sage Publications India. Green, N. (2012). Sufism: A Global History. Wiley Blackwell.

Hoque, M., \& Talukdar, D. H. (2018). Propagation of Social Harmony in Barak valley by Sufi Personalities. Pratidhwani

the Echo, VI(III), 175-179.

Ismail, M. (1989). Development of Sufism in Bengal (Doctoral dissertation, Aligarh Muslim University). Matin, A. (2018). Socio-Religious Reform and Sufism in 20th Century Bengal: A Study of the Role of Pir Abu Bakr of

Furfura Sharif, India. South Asian Cultural Studies, 25-33. 
Nasir, R K. \& Madhubanti, T, 2021

Mumtaz, N. (2010). Sufis and their Contribution to the Cultural Life of Medieval Assam in 16-17th Century (Doctoral dissertation, Aligarh Muslim University).

Rahman, M. S. N. (2018). Religious and cultural syncretism in medieval Bengal.

Rizvi, S. A. A. (1978). A History of Sufism in India: Vol. 1. Munshiram Manoharlal Publications.

Sinha, S. K. (2014). Exploring Little Tradition of Folk Islam in Bengal: A Study of Marefati Folk Songs. Proceedings of the Indian History Congress, Vol. 75, 764-770.

Stace, W. T. (1961). Mysticism and Philosophy. MacMillan and Co. Ltd.

Talukdar, D. H. (2015). A study on Sufi Saints in Karimganj District of Assam (1346-1947). Pratidhwani the Echo, III(IV), 73-78.

Trottier, A. (2000). A Case of Grassroots Syncretic Sufism: The Fakir of Bengal. ISIM Newsletter, 5(1), 17-17.

Wasey, A. \& Ehsas, F. (Eds.) (2011). Sufism and Indian Mysticism. Readworthy Publications. 